\title{
ANALISIS FUNGSI REKREASI DI RUANG TERBUKA HIJAU KOTA BANDUNG (Studi Kasus: Taman Lansia dan Teras Cikapundung)
}

\author{
Dea Intan Novia Ratnafury ${ }^{(1)}$, Fitri Rahmafitria ${ }^{(2)}$, Upi Supriatna ${ }^{(3)}$ \\ (1)(2)(3) Program Studi Manajemen Resort \& Leisure \\ Universitas Pendidikan Indonesia \\ deaaintan1@gmail.com
}

\begin{abstract}
ABSTRAK
Masyarakat kota memiliki jalan kehidupan yang cepat atau disebut juga mobilitas tinggi, terkadang waktu akhir pekan digunakan untuk menyelesaikan pekerjaan. Oleh karena itu dibutuhkan alternatif tempat untuk berekreasi yang dekat dengan pemukiman dan berada di tengah-tengah kota. Ruang Terbuka Hijau dalam hal ini Taman Kota bisa menjadi pilihan yang tepat untuk dijadikan alternatif tempat berekreasi. Penelitian ini bertujuan untuk mengidentifikasi fungsi rekreasi di Ruang Terbuka Hijau Kota Bandung. Penelitian ini menggunakan metode deskriptif kuantitatif dengan uji hipotesis beda rata-rata (Independent $t$ test). Populasi dalam penelitian ini adalah masyarakat Kota Bandung yang menggunakan ruang terbuka hijau dan seluruh Ruang Terbuka Hijau di Kota Bandung. Sampel yang dipilih untuk sampel wilayah adalah Taman Lansia dan Teras Cikapundung, sedangkan sampel responden sebanyak 100 responden di masing-masing taman kota pada penelitian ini. Berdasarkan hasil penelitian diperoleh bahwa terdapat perbedaan fungsi rekreasi yang dirasakan pengunjung di masing-masing taman. Berdasarkan hasil penelitian ini diharapkan Pemerintah Kota Bandung bisa meningkatkan elemen fungsi rekreasi di Ruang Terbuka Hijau atau taman kota, sehingga bisa digunakan masyarakat untuk alternatif tempat berekreasi.
\end{abstract}

Kata Kunci: Rekreasi, Ruang Terbuka Hijau, Perkotaan, Taman Kota

\section{AN ANALYSIS OF RECREATION FUNTION AT GREEN OPENSPACE IN BANDUNG CITY}

\begin{abstract}
The urban community has a high mobility, sometimes the weekend is used to complete their work. Therefore it needed the alternative places for recreation that close to the residence and located at the center of the city. Green Openspace in this case city park can be the right choice to be an alternative place of recreation. This research aims to identify the function of recreation at green openspace in Bandung City. The research used quantitative descriptive method with hypothesis test of average difference (Independent $t$-test). The participants of this research is the citizens of Bandung City who visited the city park repearedly and all the green openspace in Bandung City. The samples of this research are Taman Lansia and Teras Cikapundung, while the sample of respondents are 100 respondents in each of the city park. The result of this research claim that the recreation function that the visitors perceived is different in each city park. Base on the result of this research is expected the goverment of Bandung City could improve the element of recreation fuction in green openspace or city park that can be the alternative place for recreation.
\end{abstract}

Keyword : Recreation, Green Openspace, Urban, City Park 


\section{PENDAHULUAN}

Rekreasi adalah kegiatan yang dilakukan untuk penyegaran kembali jasmani dan rohani seseorang yang sudah lelah dengan rutinitas sehari-hari. Menurut Bonniface dan Cooper (1998) jika dilihat dari waktu dan jarak yang ditempuh maka kegiatan waktu luang terbagi menjadi dua yaitu waktu luang pendek dan waktu luang panjang. Waktu luang pendek terdiri dari home-based recreation dan daily leisure dimana aktivitas rekreasi yang dilakukan adalah di luar rumah maupun di sekitar rumah seperti membaca, berkebun, olahraga, berjalan-jalan di taman, dan lain sebagainya. Sedangkan waktu luang panjang terdiri dari day trip dan tourism (wisata), aktivitas yang dilakukan adalah melakukan perjalanan semenetara dari suatu daerah dengan tujuan diluar lingkungan rumah dan tempat kerja biasa. Dalam hal ini kegiatan waktu luang dan aktivitas rekreasi dapat dapat digambarkan sebagai berikut:

Tabel 1. Hubungan Waktu Luang Dan Aktivitas Rekreasi

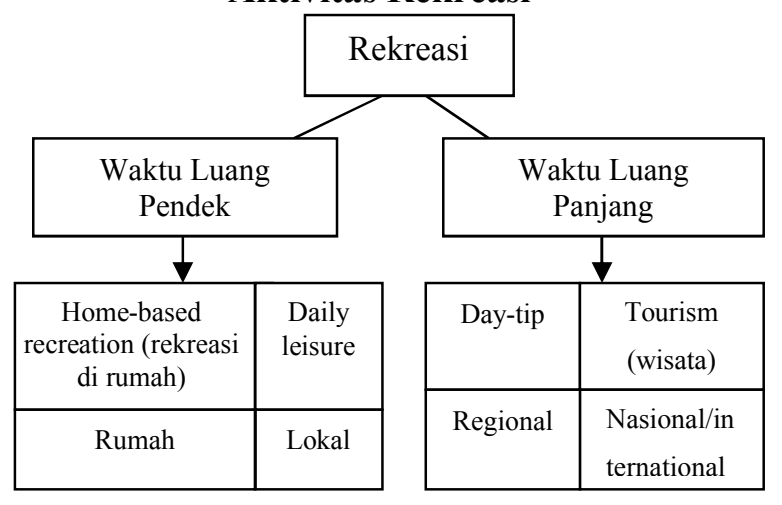

Sumber: Ardiansyar Fikry 2014

Berdasarkan Tabel 1 diatas, dapat disimpulkan bahwa setiap individu masyarakat kota dengan mobilitas tinggi rata-rata di setiap harinya tidak memiliki waktu luang yang panjang untuk melakukan perjalanan wisata sebagai kegiatan rekreasi. Bagi masyarakat kota yang hanya memiliki waktu luang pendek aktivitas yang dilakukan sangat terbatas seperti membaca buku, membaca majalah, mendengarkan musik, atau hanya sekedar berjalan-jalan di sekitar rumah atau di sekitar tempat bekerjanya. Kegiatan rekreasi sangatlah penting karena mempunyai khasiat untuk menyegarkan pikiran dengan melakukan kegiatan rekreasi maka akan meningkatkan kualitas pekerjaan. Melakukan kegiatan rekreasi tidak dipungkiri membutuhkan juga suatu area yang dapat digunakan untuk kegiatan atau aktivitas rekreasi. Dalam hal ini karena area wilayah kota sangat terbatas maka masyarakat kota dapat memanfaatkan sarana Ruang Terbuka Hijau yang dapat digunakan oleh publik. Jika dilihat dari fungsinya Ruang Terbuka Hijau (RTH) perkotaan dapat dibedakan menjadi RTH alami seperti kawasan lindung dan RTH non alami atau RTH binaan seperti taman, lapangan olahraga, jalur hijau dan pemakaman. Dengan pengelompokan jenis tersebut, RTH memiliki beragam fungsi baik intrinsik (fungsi utama) yaitu sebagai produsen oksigen $(\mathrm{O} 2)$ dan penyerap polusi (CO2), maupun ekstrinsik (fungsi tambahan) yaitu tempat rekreasi dan media komunikasi warga kota.

Bandung merupakan salah satu kota besar di Indonesia yang sekarang sudah beranjak menjadi kota metropolitan terbesar di Jawa Barat. Pada saat ini Pemerintah Kota Bandung sangatlah gencar dalam menata wajah kota, salah satunya dengan membangun Ruang Terbuka Hijau di berbagai penjuru Kota Bandung. Mengingat fungsi Ruang Terbuka Hijau yang sangat banyak maka tak tanggung-tanggung Pemerintah Kota Bandung sudah merencanakan pembangunan Ruang Terbuka Hijau. Berikut adalah tabel rencana pembangunan Ruang Terbuka Hijau di Kota Bandung:

Tabel 2. RTH Eksisting dan RTH

Rencana Kota Bandung berdasarkan RTRW Kota Bandung 2011-2031

\begin{tabular}{lcccc}
\hline \multirow{2}{*}{ Jenis RTH } & \multicolumn{2}{c}{ Eksisting } & \multicolumn{2}{c}{ Rencana } \\
\cline { 2 - 5 } & $\begin{array}{c}\text { Luas } \\
\text { (Ha) }\end{array}$ & $\%$ & $\begin{array}{c}\text { Luas } \\
\text { (Ha) }\end{array}$ & $\%$ \\
\hline $\begin{array}{l}\text { Sempadan } \\
\text { Sungai }\end{array}$ & 18,31 & 0,11 & 18,31 & 0,11 \\
\hline $\begin{array}{l}\text { Sempadan rel } \\
\text { kereta }\end{array}$ & 6,48 & 0,04 & 9,63 & 0,06 \\
\hline Sempadan SUTT & 10,17 & 0,07 & 10,17 & 0,07 \\
\hline
\end{tabular}


Dea Intan Novia Ratanfury, Fitri Rahmafitria dan Upi Supriatna : Analisis Fungsi Rekreasi di Ruang Terbuka Hijau Kota Bandung (Studi Kasus: Taman Lansia dan Teras Cikapundung)

\begin{tabular}{|c|c|c|c|c|}
\hline \multirow[b]{2}{*}{ Jenis RTH } & \multicolumn{2}{|c|}{ Eksisting } & \multicolumn{2}{|c|}{ Rencana } \\
\hline & $\begin{array}{c}\text { Luas } \\
\text { (Ha) }\end{array}$ & $\%$ & $\begin{array}{l}\text { Luas } \\
\text { (Ha) }\end{array}$ & $\%$ \\
\hline Sempadan jalan & 176,91 & 1,06 & 264,34 & 1,58 \\
\hline Taman kota & 218,07 & 1,3 & 2713,9 & 15,92 \\
\hline TPU & 148,14 & 0,89 & 292 & 1,74 \\
\hline $\begin{array}{l}\text { Kawasan } \\
\text { konservasi }\end{array}$ & 4,12 & 0,02 & 4,12 & 0,02 \\
\hline Lain-lain & 436,4 & 2,61 & 92,58 & 0,55 \\
\hline RTH PUBLIK & 1018,54 & 6,1 & 3404,05 & 20,00 \\
\hline Perumahan & 55,6 & 0,33 & 1090 & 6,36 \\
\hline Hankam & 114,01 & 0,68 & 60,84 & 0,36 \\
\hline $\begin{array}{l}\text { Pendidikan, } \\
\text { perdagangan }\end{array}$ & 722,34 & 4,32 & 549,25 & 3,28 \\
\hline RTH PRIVAT & 891,95 & 5,33 & 1700,09 & 10 \\
\hline $\begin{array}{l}\text { RTH Kota } \\
\text { Bandung }\end{array}$ & 1910,49 & 11,43 & 5104,14 & 30,00 \\
\hline
\end{tabular}

Sumber: Master Plan Ruang Terbuka Hijau Kota Bandung 2012-2031 (Pemkot Bandung 2012)

Jika dilihat dari Tabel 2 diatas perencanaan pembangunan Ruang Terbuka Hijau di Kota Bandung memang sangat besar. Pembangunan ini juga berhubungan dengan program pemerintah Kota Bandung yaitu peningkatan indeks kebahagian (index of happiness) warga kota yang diukur berdasarkan aktivitas warga yang berkumpul pada sebuah ruang publik dan melakukan banyak aktivitas bersama daripada berdiam diri di dalam rumah. Dalam pembangunannya taman kota mendapat sorotan yang sangat tinggi, terlihat dari jumlah luas taman kota pada tabel diatas yaitu sebesar 218,07 Ha. Pembangunan taman kota yang massive membuat masyarakat tertarik untuk mengunjungi taman. Salah satu fungsi taman menurut INMENDAGRI No 14 Tahun 1988 yaitu sebagai sarana rekreasi. Lokasi yang strategis, beragam fasilitas yang tersedia menjadi pilihan masyarakat untuk berkunjung, menurut hasil prapenelitian yang peneliti lakukan masih ada yang kurang yaitu kenyamanan dalam hal kebersihan seperti berserakannya sampah dan taman yang kurang ramah terhadap penyandang disabilitas. Maka peneliti berfikir untuk melakukan penelitian untuk meningkatkan fungsi rekreasi di taman kota. Menurut teori dari Krippendorf dalam Pitana (2005) suatu tempat disebutkan mempunyai fungsi rekreasi yang ideal apabila bisa menyegarkan fisik pengunjung, menyegarkan mental pengunjung, menjadi sarana untuk bersosialisasi dengan orang lain dan menambah wawasan pengunjung.

Dalam elemen Tourism Opportunity Spectrum yang dikemukakan Butler \& Waldbrook (2003) menyebutkan bahwa karakteristik sarana pariwisata termasuk didalamnya pengadaan fasilitas menentukan keberhasilan pengembangan pariwisata. Menimbang dari teori tersebut maka dalam penelitian ini peneliti memilih dua lokasi untuk dijadikan studi kasus penelitian yaitu Taman Lansia dan Teras Cikapundung. Pemilihan lokasi ini dipertimbangkan berdasarkan kelengkapan fasilitas rekreasi, Taman Lansia untuk mewakili taman dengan fasilitas rekreasi yang sederhana dan Teras Cikapundung mewakili taman dengan fasilitas rekreasi yang lengkap. Kedua lokasi ini juga dipilih untuk membandingkan fungsi rekreasi yang dirasakan pengunjung di kedua taman dengan karakteristik yang sudah disebutkan sebelumnya, sehingga dapat diketahui perbedaan dari kedua karakteritik taman ini. Jumlah pengunjung kedua taman ini menurut prapenelitian yang dilakukan peneliti diperkirakan mencapai 100 orang perminggunya dengan rata-rata 14-13 pengunjung perhari.

Tujuan dari penelitian ini adalah untuk menganalisis fungsi rekreasi di Ruang Terbuka Hijau dengan mempertimbangkan fungsi rekreasi menurut Krippendorf dalam Pitana (2005) yaitu sebagai wahana penyegaran fisik, wahana penyegaran mental, sarana untuk bersosialisasi dengan orang lain dan sebagai wahana untuk menambah wawasan. Hasil penelitian ini dapat digunakan sebagai pertimbangan untuk mengembangkan taman dengan memperhatikan aspek fungsi rekreasi di RTH. 


\section{LANDASAN TEORI \\ Ruang Terbuka Hijau}

Dalam PerMen PU No. 5/PRT/M/ 2008 dijelaskan bahwa Ruang Terbuka Hijau merupakan area memanjang/jalur dan atau mengelompok yang penggunaannya lebih bersifat terbuka, tempat tumbuh tanaman baik yang tumbuh secara alamiah maupun yang sengaja ditanam.

Fungsi Ruang Terbuka Hijau kota berdasarkan Inmendagri No.14/1988 yaitu sebagai:

1. Areal perlindungan berlangsungnya fungsi ekosistem dan penyangga kehidupan

2. Sarana untuk menciptakan kebersihan, kesehatan, keserasian dan keindahan lingkungan

3. Sarana rekreasi

4. Pengaman lingkungan hidup perkotaan terhadap berbagai macam pencemaran baik darat, perairan maupun udara

5. Sarana penelitian dan pendidikan serta penyuluhan bagi masyarakat untuk membentuk kesadaran lingkungan

6. Tempat perlindungan plasma nutfah

7. Sarana untuk mempengaruhi dan memperbaiki iklim mikro

8. Pengatur tata air

\section{Rekrasi}

Rekreasi merupakan aktivitas dimana partisipasinya telah memiliki untuk terikat atau terlibat. Hal ini sangat penting dimana kata rekreasi dimaksud sebagai penggunaan waktu luang secara aktif dalam gaya hidup seseorang (Williams, 1995).

Menurut Krippendorf dalam Pitana $(2005 ; 63)$ fungsi rekreasi yaitu sebagai berikut:

1. Wahana penyegaran fisik

2. Wahana penyegaran mental

3. Sarana untuk bersosialisasi dengan orang lain

4. Wahana untuk menambah wawaasan

Pola Rekreasi dan Aktivitas Rekreasi di Ruang Terbuka Hijau

Pola rekreasi dibentuk oleh interaksi antar penyedia kesempatan berekreasi dengan partisipan itu sendiri. Pola umum penggunaan ruang terbuka kota antara lain menarik pengunjung yang besar dari komunitas kota, dimana taman tersebut merupakan fasilitas lokal dengan $60-80 \%$ pengunjungnya berasal dari areal 2 kilometer dari taman (Williams, 1995). Hal serupa juga diungkapkan oleh (Woolley,2003), orang-orang yang bertemu di taman kota adalah mereka yang tinggal maupun bekerja di areal tersebut, dan menempuh perjalanan pendek sekitar 0,2 kilometer atau lebih.

Menurut Delianur (2000), aktivitas rekreasi yang dapat dilakukan di ruang terbuka harus memenuhi 2 kategori, yaitu:

1. Aktivitas Rekreasi Aktif

a. Olahraga. Maka harus diadakan fasilitas yang menunjang untuk berolaraga seperti, jalur untuk jogging, besepeda, lahan untuk senam dan lain sebagainnya.

b. Bermain. Maka harus disediakan fasilitas untuk bermain, seperti ayunan, kolam pasir untuk anak-anak dan lain sebagainya.

2. Aktivitas Pasif

a. Tempat beristirahat. Maka harus diadakan fasilitas untuk beristirahat seperti, tempat duduk, gazeboo dan lain sebagainya.

\section{METODE}

Penelitian ini dilaksanakan di Taman Lansia dan Teras Cikapundung. Pemilihan kedua taman ini di dasarkan pada fasilitas taman yang tersedia, menurut elemen Tourism Opportuity Spectrum menyatakan bahwa pengadaan fasilitas menentukan keberhasilan pengembangan pariwisata. Taman Lansia mewakili taman yang banyak dikunjungi namun fasilitas yang tersedia tidak terlalu banyak, sedangkan Teras Cikapundung mewakili taman yang banyak dikunjungi dengan fasilitas yang banyak. Taman Lansia berlokasi di jalan Cisangkuy, Citarum tepatnya di sebelah kanan Gedung Sate. Teras Cikapundung adalah taman yang berada di tepian sungai Cikapundung, tepatnya di Jalan Siliwangi No 28 Coblong. 
Dea Intan Novia Ratanfury, Fitri Rahmafitria dan Upi Supriatna : Analisis Fungsi Rekreasi di Ruang Terbuka Hijau Kota Bandung (Studi Kasus: Taman Lansia dan Teras Cikapundung)

Metode yang digunakan pada penelitian ini adalah metode dekriptif dengan pendekatan kuantitatif.

Populasi wilayah pada penelitian ini adalah RTH di Kota Bandung. Populasi responden penelitian ini melingkupi penduduk Kota Bandung yang yang mengunjungi RTH. Sampel yang diambil untuk sampel wilayah yairu Taman Lansia dan Teras Cikapundung, kedua taman ini dipilih untuk mewakili RTH berdasarkan kelengkapan fasilitasnya, Taman Lansia mewakili taman dengan fasilitas sederhana dan Teras Cikapundung mewakili taman dengan fasilitas yang lengkap. Sedangkan, pengambilan sampel responden sebanyak 100 di masing-masing tempat, jumlah didapatkan berdasarkan rumus Slovin.

Untuk menganalisis fungsi rekreasi yang dirasakan pengunjung di RTH pada penelitian ini variabel yang digunakan adalah teori Kripendorf dalam Pitana (2005) mengenai fungsi rekreasi yaitu sebagai wahana penyegaran fisik, wahana penyegaran mental, sarana untuk bersosialisasi dengan orang lain dan wahana untuk menambah wawasan.

Teknik pengumpulan data pada penelitian ini menggunakan teknik observasi dan kuesioner sebagai sumber data. Sedangkan, data sekunder diperoleh dari studi literatur. Kuisioner pada penelitian ini menggunakan pendekatan pengukuran skala likert. Untuk analisis data penelitian ini menggunakan tabulasi data dengan menggunakan Microsoft Excel 2010, perhitungan MSI (Method Success Interval), dan garis kontinum dengan menggunakan software SPSS 20. Setelah itu dilakukan Uji Validitas dan Uji Reliabilitas dan Uji Normalitas. Dan untuk membandingkan persepsi pengunjung mengenai fungsi rekreasi di kedua tempat penelitian digunakan analisis $t$-test, rumus yang digunakan yaitu Separated Varians untuk Uji $\mathrm{T}$ dengan varian yang berbeda (unequal variance):

$$
t=\frac{\bar{X}_{1}-\bar{X}_{2}}{\sqrt{\frac{S_{1}^{2}}{n_{1}}+\frac{S_{2}^{2}}{n_{2}}}}
$$

Ketentuan dari uji hipotesis ini adalah:

$\mathrm{H}_{0} \quad$ : Tidak ada perbedaan fungsi rekreasi yang dirasakan pengunjung

$\mathrm{H}_{1}$ : Terdapat perbedaan fungsi rekreasi yang dirasakan pengunjung

Kriteria penolakan hipotesisnya adalah:

1) Jika $t_{\text {hitung }} \geq t_{\text {tabel }}$ maka $\mathrm{H}_{0}$ ditolak dan $\mathrm{H}_{1}$ diterima

2) Jika thitung $\leq$ ttabel maka $\mathrm{H}_{0}$ diterima dan $\mathrm{H}_{1}$ ditolak

\section{HASIL DAN PEMBAHASAN}

Taman Lansia adalah salah satu ruang terbuka hijau berjenis taman kota yang terletak di tengah-tengah kota bandung. Terletak disebelah kanan Gedung Sate dan diresmikan pada tanggal 31 Desember 2014 oleh Wali Kota Bandung Ridwan Kamil. Taman ini dahulu bernama Taman Cisangkuy karena letaknya di jalan Cisangkuy dan Jalan Cilaki, namun namanya menjadi berubah karena banyak kalangan lanjut usia yang banyak berkunjung ke taman ini, namun sekarang tidak hanya kalangan lanjut usia yang berkunjung ke taman ini, melainkan kalangan mudapun banyak berkunjung ke taman ini.

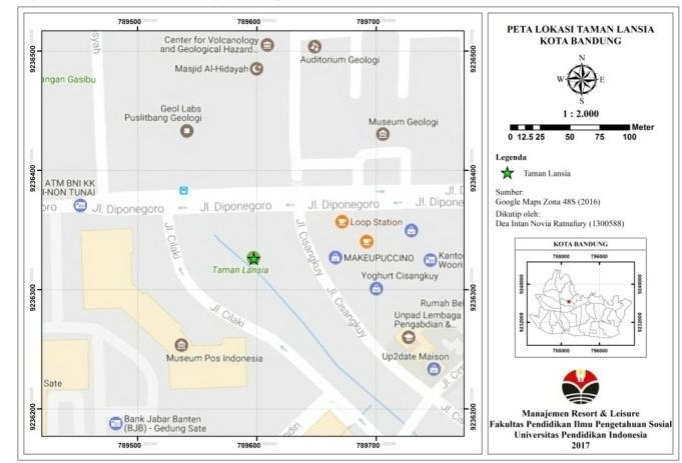

Gambar 1. Peta Lokasi Taman Lansia

Sumber: diadopsi dari Google Maps (2017)

Teras Cikapundung berlokasi di Babakan Siliwangi lebih tepatnya di bantaran sungai Cikapundung. Dibangun diatas lahan seluas 1.800 meter, dahulunya kawasan bantaran sungai Cikapundung ini 
dimanfaatkan sebagai kawasan pemukimam ilegal oleh warga. Sungai di kota bandung kebanyakan sudah tercemar oleh limbahlimbah seperti limbah ternak, pertanian, limbah rumah tangga dan limbah industri, oleh karena itu pemerinta merancang taman ini dalam rangka sebagai salah satu upaya mengembalikan fungsi sungai dengan meresorasi sempadannya. Sungai yang melintang sepanjang $28 \mathrm{KM}$ ini bersumber dari daerah Maribaya sebagai hulu sungai dan mengalir ke selatan melalui kota Bandung dan bermuara ke sungai citarum daerah Dayeuhkolot.

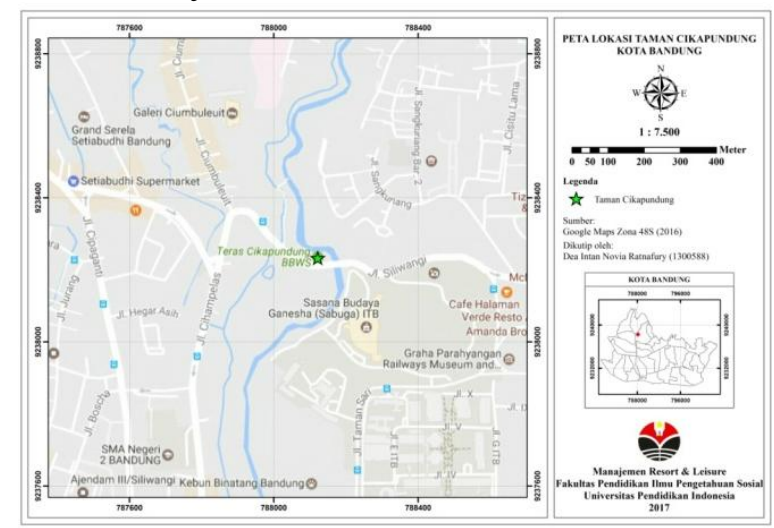

Gambar 2. Peta Lokasi Teras Cikapundung Sumber: diadopsi dari Google Maps (2017)

Karakteristik pengunjung di kedua tempat adalah sebagai berikut, pengunjung Taman Lansia berdasarkan jenis kelamin perempuan (61\%), usia $20-25$ tahun $(58 \%)$, asal Kota Bandung (56\%), jumlah kunjungan $>3$ kali $(37 \%)$, status pekerjaan sebagai mahasiswa (47\%), pendidikan terakhir SMA (49\%), status belum menikah (73\%), penghasilan Rp. 0,- s/d Rp.1.000.000,- (51\%), menghabiskan waktu 2 jam (37\%), sumber informasi dari teman (47\%). Sedangkan pengunjung Teras Cikapundung adalah sebagai berikut, jenis kelamin perempuan (60\%), usia 20-25 tahun $(53 \%)$, asal Kota Bandung (60\%), jumlah kunjungan 1 kali (40\%), status pekerjaan sebagai mahasiswa (46\%), pendidikan terakhir SMA (58\%), status belum menikah (73\%), penghasilan Rp. 0,- s/d Rp.1.000.000,- (72\%), menghabiskan waktu
2 jam (46\%), sumber informasi dari saudara $(68 \%)$.

Berdasakan persepsi pengunjung terhadap kepentingan fungsi rekreasi di Ruang Terbuaka Hijau diteliti berdasarkan fungsi rekreasi menurut Kripendorf. Yaitu sebagai Wahana Penyegaran Fisik, Penyegaran Mental, Sarana Bersosialisasi Dengan Orang Lain dan Wahana Penambahan Informasi. Berikut adalah hasil yang diperoleh di Taman Lansia:

Tabel 3. Rekapitulasi Persepsi

Pengunjung Terhadap Kepentingan

Fungsi Rekreasi Di Taman Lansia

\begin{tabular}{|c|c|c|c|c|}
\hline No & Sub Variabel & $\begin{array}{l}\text { Skor } \\
\text { Total }\end{array}$ & $\begin{array}{c}\text { Persentase } \\
(\%)\end{array}$ & $\begin{array}{l}\text { Kategori } \\
\text { fungsi } \\
\text { rekreasi }\end{array}$ \\
\hline 1 & $\begin{array}{l}\text { Wahana } \\
\text { Penyegaran Fisik }\end{array}$ & 1022 & $68,1 \%$ & Setuju \\
\hline 2 & $\begin{array}{l}\text { Wahana } \\
\text { Penyegaran } \\
\text { Mental }\end{array}$ & 1525 & $61 \%$ & Cukup \\
\hline 3 & $\begin{array}{l}\text { Sarana untuk } \\
\text { bersosialisasi } \\
\text { dengan orang lain }\end{array}$ & 1042 & $69,4 \%$ & Setuju \\
\hline 4 & $\begin{array}{l}\text { Wahana untuk } \\
\text { menambah } \\
\text { wawasan. }\end{array}$ & 1169 & $58,4 \%$ & Cukup \\
\hline & $\begin{array}{l}\text { tal Keseluruhan } \\
\text { Skor }\end{array}$ & 4738 & $60,3 \%$ & Cukup \\
\hline
\end{tabular}

Sumber: diolah peneliti (2017)

Berdasarkan tabel diatas, sub variabel Wahana Penyegaran Fisik berada pada katagori setuju, faktor yang mempengaruhi hal tersebut adalah Taman Lansia bisa dijadikan sebagai tempat alternatif untuk berolahraga, karena terdapat jalur untuk berjalan-jalan santai atau jogging, serta adanya kegiatan senam setiap hari kamis. Pada sub variabel Wahana Penyegaran Mental berada di kategori cukup, rindangnya pohon-pohon yang ada di Taman Lansia memberikan rasa nyaman yang cukup, namun sedikit terganggu karena pedagang kaki lima dan perawatan kebersihan sekitar taman. Pada sub variabel Sarana Untuk Bersosialisasi Dengan Orang Lain berada pada katagori setuju, ketersediaan ruang yang cukup luas untuk berkumpul dengan dengan komunitas maupun keluarga menjadi 
Dea Intan Novia Ratanfury, Fitri Rahmafitria dan Upi Supriatna : Analisis Fungsi Rekreasi di Ruang Terbuka Hijau Kota Bandung (Studi Kasus: Taman Lansia dan Teras Cikapundung)

alasan pengunjung memberikan nilai setuju. Terakhir sub variabel Wahana Untuk Menambah Wawasan berada pada kategori cukup, kurang lengkapnya informasi yang tersedia di papan inofrmasi menjadi faktor pengunjung hanya memberikan nilai cukup.

Persepsi pengunjung terhadap fungsi rekreasi di Taman Lansia memiliki nilai rata-rata presentase sebesar $60,3 \%$. Dimana termasuk kedalam katagori cukup, dengan skor total 4738 menyebutkan bahwa katagori cukup mendekati setuju sehingga fungsi rekreasi di Taman Lansia berkatagori cukup namun sudah mendekati kategori setuju sehingga perlu di tingkatkan variabel dalam fungsi rekreasi diluar varibel sebagai wahana untuk menyegarkan fisik dan menambah wawasan.

Sebaliknya di Teras Cikapundung persepsi pengunjung terhadap kepentingan fungsi rekreasi di Ruang Terbuaka Hijau berada pada nilai yang cukup pada semua fungsi rekreasi.

Tabel 4. Rekapitulasi Persepsi Pengunjung Terhadap Kepentingan Fungsi Rekreasi Di Teras Cikapundung

\begin{tabular}{|c|c|c|c|c|}
\hline No & Sub Variabel & $\begin{array}{l}\text { Skor } \\
\text { Total }\end{array}$ & $\begin{array}{c}\text { Persentase } \\
(\%)\end{array}$ & $\begin{array}{l}\text { Kategori } \\
\text { fungsi } \\
\text { rekreasi }\end{array}$ \\
\hline 1 & $\begin{array}{l}\text { Wahana } \\
\text { Penyegaran Fisik }\end{array}$ & 863 & $55,7 \%$ & Cukup \\
\hline 2 & $\begin{array}{l}\text { Wahana } \\
\text { Penyegaran } \\
\text { Mental }\end{array}$ & 1420 & $56,8 \%$ & Cukup \\
\hline 3 & $\begin{array}{l}\text { Sarana untuk } \\
\text { bersosialisasi } \\
\text { dengan orang } \\
\text { lain }\end{array}$ & 875 & $62,2 \%$ & Cukup \\
\hline 4 & $\begin{array}{l}\text { Wahana untuk } \\
\text { menambah } \\
\text { wawasan. }\end{array}$ & 1178 & $58,9 \%$ & Cukup \\
\hline & $\begin{array}{l}\text { tal Keseluruhan } \\
\text { Skor }\end{array}$ & 4309 & $57,8 \%$ & Cukup \\
\hline
\end{tabular}

Sumber: diolah peneliti (2017)

Berdasarkan tabel 4 diatas, persepsi pengunjung terhadap fungsi rekreasi di Teras Cikapundung pada sub variabel Wahana Penyegaran Fisik berada pada kategori cukup, Pengunjung memberikan nilai cukup karena fasilitas untuk berolaraga tidak ada dan suasana yang kurang teduh karena tidak ada pepohonan rindang sehingga kurang memberikan efek rileks terhadap tubuh. Pada sub variabel Wahana Penyegaran Mental berada di kategori cukup, ketersedian fasilitas dan pemandangan menjadi faktor pengunjung memberikan nilai cukup. Sub variabel Sarana Untuk Bersosialisasi Dengan orang Lain berada pada kategori cukup, lahan untuk berkumpul bersama komunitas maupun keluarga masih kurang, hanya ada satu gazeboo yang tersedia, sehingga komunitas maupun keluarga kurang nyaman untuk berkumpul menjadi faktor dari katagori tersebut. Pada sub variabel Wahana Untuk Menambah Wawasan berada di kategori cukup, di Teras Cikapundung belum ada papan informasi yang lengkap, sehingga pengunjung memberikan nilai cukup.

Persepsi pengunjung terhadap fungsi rekreasi di Teras Cikapundung memiliki nilai rata-rata presentase sebesar 57,8\%. Dimana termasuk kedalam katagori cukup. Maka dengan ini variabel dalam fungsi rekreasi harus di tingkatkan lagi, baik dari fasilitas yang menunjang maupun suasana alam yang harus dijaga.

Perbedaan fungsi rekreasi di Taman Lansia dan Teras Cikapundung dianalisis menggunakan independent sample t-test yang digunakan untuk mengetahui perbedaan mean atau rata-rata 2 kelompok sampel yang tidak berpasangan. Uji independent t-test digunakan untuk mengetahui ada atau tidaknya perbedaan rata - rata fungsi rekreasi yang dirasakan pengunjung di masing-masing taman.

Tabel 5. Rekapitulasi Uji T Fungsi Rekreasi Ruang Terbuka Hijau Di Taman Lansia dan Teras Cikapundung

\begin{tabular}{|c|c|c|}
\hline \multirow{2}{*}{ Sub Varibel } & \multicolumn{2}{|c|}{$\begin{array}{c}\text { Persepsi Pengunjung } \\
\text { Mengnai Fungsi Rekreasi }\end{array}$} \\
\hline & $\begin{array}{l}\text { Taman } \\
\text { Lansia }\end{array}$ & $\begin{array}{c}\text { Teras } \\
\text { Cikapundung }\end{array}$ \\
\hline $\begin{array}{l}\text { Wahana } \\
\text { Penyegaran Fisik }\end{array}$ & Tinggi & Cukup \\
\hline $\begin{array}{l}\text { Wahana } \\
\text { Penyegaran Mental }\end{array}$ & Cukup & Cukup \\
\hline
\end{tabular}




\begin{tabular}{|c|c|c|}
\hline \multirow{2}{*}{ Sub Varibel } & \multicolumn{2}{|c|}{$\begin{array}{c}\text { Persepsi Pengunjung } \\
\text { Mengnai Fungsi Rekreasi }\end{array}$} \\
\hline & $\begin{array}{l}\text { Taman } \\
\text { Lansia }\end{array}$ & $\begin{array}{c}\text { Teras } \\
\text { Cikapundung }\end{array}$ \\
\hline $\begin{array}{l}\text { Sarana Untuk } \\
\text { Bersosialisasi } \\
\text { dengan Orang lain }\end{array}$ & Tinggi & Cukup \\
\hline $\begin{array}{l}\text { Wahana untuk } \\
\text { menambah } \\
\text { wawasan }\end{array}$ & Cukup & Cukup \\
\hline
\end{tabular}

Berdasarkan tabel 5 di atas bisa dilihat bahwa hasil dari penelitian ini menggambarkan fungsi rekreasi di Taman Lansia dan Teras Cikapundung terdapat perbedaan. Perbedaan yang ada yaitu pada variabel wahana penyegara fisik dan sebagai sarana untuk bersosialisasi dengan orang lain.

Perbedaan yang ada di variabel wahana penyegaran fisik di sebabkan karena kurangnya fasilitas olahraga dan kegiatan olahraga yang dapat dilakukan. Pengunjung Taman lansia biasa melakukan aktivitas olahraga ditaman dengan memanfaatkan jalur yang ada sebagai jalur untuk berjalan santai ataupun jogging dan juga memanfaatkan lahan yang luas dan teduh di Taman Lansia untuk melakukan olahraga senam, sedangkan di Teras Cikapundung lahan yang luas sudah tersedia namun kenyamanannya agak kurang karena tidak ada penghalang dari teriknya matahari seperti pohon. Oleh karena itu ada perbedaan fungsi rekreasi sebagai wahana penyegaran fisik yang dirasakan pengunjung.

Pada variabel wahana penyegaran mental tidak ada perbedaan di kedua taman tersebut, pengunjung menyatakan fungsi rekreasi yang dirasakan cukup. Pengunjung menilai cukup pada variabel ini karena kedua taman memberikan penyegaran mental kepada pengunjung, penyegaran mental yang didapatkan oleh pungunjung berasal dari kegiatan yang dapat dilakukan pengunjung dan suasana yang dapat pengunjung rasakan di kedua taman tersebut. Kegiatan yang menyegarkan mental yaitu melihat pemandangan taman seperti pepohonan yang ada di Taman Lansia dan aliran air sungai di Teras Cikapundung, sedangkan susana yang dapat menyegarkan mental yaitu kesejukan, gemercik air sungai dan hembusan angin.

Pada variabel sebagai sarana untuk bersosialisasi dengan orang lain, kedua tempat tersebut menunjukan perbedaan fungsi rekreasi yang dirasakan pengujung. Perbedaan ini disebabkan karena pengunjung lebih merasa Taman Lansia adalah tempat yang cocok untuk berkumpul dengan keluarga, kerabat maupun komunitas. Ketersediaan lahan yang luas dan teduh menjadi faktor dijadikannya Taman Lansia sebagai saran bersosialisasi dengan keluarga, kerabat maupun komunitas. Sedangkan Teras Cikapundung pengunjung memberikan nilai cukup karena tempat untuk berkumpul dan teduh seperti gazeboo terbatas keberadaannya.

Pada variabel sebagai wahana untuk menambah wawasan tidak ada perbedaan. Tidak ada perbedaan ini disebabkan karena keberadaan papan informasi di kedua tempat ini belum terlalu baik, dilihat dari isi informasinya yang belum lengkap dan desain yang kurang menarik pengujung untuk membaca.

\section{KESIMPULAN}

Berdasarkan pengolahan data dan hasil yang diperoleh dapat disimpulkan bahwa karakteritik pengguna taman kota khusunya dalam hal ini adalah Taman Lansia dan Teras Cikapundung sangat beragam. Pengunjung Taman Lansia didominasi oleh pengunjung berusia 20-25 tahun, pengunjung dengan status belum menikah dan komunitas-komunitas yang berasal dari Kota Bandung dengan jumlah kunjungan rata-rata sudah lebih dari 3 kali dan waktu berkunjung selama 2 jam. Teras Cikapundung secara keseluruhan banyak dikunjungi muda-mudi dengan rentang umur 20-25 tahun, kebanyakan belum berstatus menikah atau masih lajang dan dengan jumlah kunjungan untuk pertama kali berkunjung. Tidak ditemukan komunitas- 
komunitas yang berkumpul di taman ini, pengunjung kebanyakan menghabiskan waktu 2 jam di taman ini dan pengunjung kebanyakan berasal dari Kota Bandung.

Persepsi pengunjung terhadap kepentingan fungsi rekreasi di Ruang Terbuaka Hijau, Taman Lansia yang mempunyai karakteristik alami, didukung dengan adanya pohon-pohon besar yang teduh namun minim akan fasilitas rekreasinya, mempunyai nilai yang tinggi untuk fungsi rekreasi sebagai wahana penyegaran fisik dan fungsi rekreasi sebagai sarana untuk bersosialisasi dengan orang lain. Untuk fungsi lainnya seperti fungsi rekreasi sebagai wahana penyegaran mental dan sebagai wahana untuk menambah wawasan, pengunjung memberikan nilai cukup. Sebaliknya di Teras Cikapundung pengunjung memberikan nilai yang cukup pada semua fungsi rekreasi.

Berdasarkan hasil yang diperoleh dari penelitian, terdapat perbedaan fungsi rekreasi yang dirasakan oleh pengunjung di kedua taman ini. Perbedaan yang terlihat yaitu diantara fungsi rekreasi sebagai wahana untuk penyegaran fisik dan fungsi rekreasi sebagai sarana untuk bersosialisasi dengan orang lain, kedua fungsi ini lebih menonjol atau tinggi di Taman Lansia. Tingginya nilai fungsi rekreasi sebagai wahana untuk penyegaran fisik di Taman Lansia dikarenakan mampu memberikan rasa bugar dan rileks terhadap tubuh penggunannya dan juga bisa menjadi alternatif tempat untuk berolahraga. Sedangkan fungsi rekreasi sebagai sarana untuk bersosialisasi memberikan kebebasan bagi pengunjung untuk bersosialisasi, taman ini bisa memfasilitasi pengunjungnya untuk bersosialisasi baik itu dengan kerabat, komunitas maupun orang lain karena tersedia lahan yang luas yang memadai untuk dijadikan tempat berkumpul.

Bagi pemerintah Kota Bandung hendaknnya dapat memperhatikan fungsi rekreasi dalam pembangunan ataupun pengembangan taman kota. Berdasarkan hasil penelitian upaya yang dapat dilakukan berdasarkan fungsi rekreasi sebagai wahana untuk penyegaran fisik yaitu, mengadakan fasilitas olahraga sehingga dapat dijadikan tempat alternatif berolahraga, memfasilitasi ruang yang luas untuk bermain. Sedangkan dari fungsi rekreasi sebagai wahana penyegaran mental hal yang harus dipertahankan yaitu suasana alami dan pemandangan di taman. Untuk fungsi rekreasi sebagai sarana bersosialisasi dengan orang lain, hal yang perlu dipertahankan dan ditingkatkan yaitu ruang atau lahan yang luas sehingga bisa digunakan untuk berkumpul dengan kerabat, memberikan suasana yang aman dan nyaman dengan meningkat kemanan di taman, memfasilitasi taman agar ramah terhadap penyandang disabelitas. Upaya yang dapat dilakukan untuk meningkatkan fungsi rekreasi sebagai wahana untuk menambah wawasan yaitu, menyediakan media interpretasi seperti papan informasi yang lengkap dan menarik untuk dibaca.

\section{DAFTAR PUSTAKA}

Ardiansyar, F. (2014). Analisis Karakteristik dan Persepsi Pengguna Taman Kota Dalam Upaya Menningkatkan Fungsi Taman Kota Sebagai Sarana Rekreasi Masyarakat di Kota Bandung (Studi Kasus: Taman Balai Kota Bandung, Taman Pasupati, Taman Musik Centrum). (Skripsi). Program Studi Manajemen Resort \& Leisure Fakultas Pendidikan Ilmu Pengetahuan Sosial, Universitas Pendidikan Indonesia, Bandung

Bonniface,B.G dan Cooper,C.P. 1998. The Geography Of Travek And Tourism. Heinnemann, Oxford.

Butler, R. dan Waldbrook, L. (2003) A New Planning Tool : The Tourism Opportunity Spectrum. Journal of Tourism and Cultural Change,1. pp. 25-36. ISSN 1476-6825

Delianur, Achmad. (2000). Perencanaan Kawasan Lapangan Merdeka di Medan. (Tesis). Program Magister Arsitektur Program Pasca Sarjana Institut Teknologi Bandung. 
Journal of Indonesian Tourism, Hospitality and Recreation --- Volume 1, Nomor 1, April 2018

Instruksi Menteri Dalam Negeri No.14. (1988). Penataan Ruang Terbuka Hijau Di Wilayah Perkotaan. Jakarta: Kementerian Dalam Negeri

Pitana, I Gde dan Putu G Gayatri .(2005) . Sosiologi Pariwisata. Yogyakarta: Andi

Pemkot Bandung. (2012). Master Plan Ruang Terbuka Hijau Kota Bandung 2012-2031.
Peraturan Menteri Pekerjaan Umum. (2008). Pedoman Penyediaan dan Pemanfaatan Ruang Terbuka Hijau Di Kawasan Perkontaan. Jakarta: Direktorat Jendral Penataan Ruang Departemen Pekerjaan Umum.

Williams, S. (1995). Outdoor Recreation and The Urban Environment. London : Routledge.

Woolley,Helen. (2003). Urban Open Spaces. New York: Spon Press. 